9.Павлова В.А. Удосконалення стратегічного управління за позицією підприємства на ринку. Європейський вектор економічного розвитку. 2013. №2 (15). С. 187-204.

10. Федоренко М.М. Адаптація моделі управління запасами для нестандартних ситуацій з урахуванням принципу зворотного зв'язку на підприємстві «Алекс і К». Вісник Донецької академії автомобільного транспорту. 2010. C. 25-30.

\title{
References
}

1.Bezghinova, L. I. (2012). Tovarni zapasy pidpryjemstva: sutnistj ta jikh sklad [Commodity stocks of the enterprise: essence and their composition] Visnyk MSU. Serija: Ekonomichni nauky. 12-21 [in Ukrainian].

2.Boghacjka, N.M. (2008). Sutnistj, meta ta zadachi upravlinnja tovarnymy zapasamy - odyn iz suchasnykh aspektiv dijaljnosti pidpryjemstva rozdribnoji torghivli [The essence, purpose and tasks of inventory management is one of the modern aspects of the activity of the retail trade enterprise]. Zbirnyk naukovykh pracj DNU. (191).180-186 [in Ukrainian].

3.Brovko, O. T. (2009). Ekonomichna sutnistj tovarnykh zapasiv ta jikh misce v systemi upravlinnja tovarnymy potokamy pidpryjemstv torghivli [The economic essence of inventory and their place in the system of management of trade flows of trade enterprises]. Visnyk Chernivecjkogho torghiveljno-ekonomichnogho instytutu. (2). 12-21 [in Ukrainian].

4.Zabolotnja, K. O. (2012). Stokhastychna modelj upravlinnja zapasamy pidpryjemstva torghivli [Stochastic model of inventory management of a trade enterprise]. Visnyk Berdjansjkogho universytetu menedzhmentu i biznesu. (2(18)). 61-64 [in Ukrainian].

5.Kolesnikov, V.P. (2013) Formuvannja ta optymizacija tovarnogho asortymentu pidpryjemstva dlja vnutrishnjogho i zovnishnjogho rynku [Formation and optimization of product range of the enterprise for the domestic and foreign markets]. Naukovi zapysky. Serija: Ekonomika. (23). 48-50 [in Ukrainian] .

6.Kreshhenko, O. V. (2014). Tovarni zapasy jak ob'jekt upravlinnja u kateghorijnomu menedzhmenti [Commodity stocks as an object of management in categorical management]. Aktualjni problemy ekonomiky. (2). 492-500. Retrieved from: http://nbuv.gov.ua/j-pdf/ape_2014_2_58.pdf [in Ukrainian].

7.Mishhuk, I.P. (2012). Formuvannja efektyvnoji polityky upravlinnja tovarnymy zapasamy torghoveljnogho pidpryjemstva [Formation of effective trade enterprise inventory management policy]. Naukovyj visnyk NLTU Ukrajiny. (22.03). $297-302$ [in Ukrainian].

8.Pavlova, V.A. (2012). Doslidzhennja torghoveljnogho asortymentu specializovanogho maghazynu jak osnova jogho optymaljnogho formuvannja [Research of the trade assortment of a specialized store as a basis for its optimal formation]. Bjuletenj mizhnarodnogho nobelivsjkogho ekonomichnogho forumu. (1(5)). 293-300 [in Ukrainian].

9.Pavlova, V.A. (2013) Udoskonalennja strateghichnogho upravlinnja za pozycijeju pidpryjemstva na rynku [Improvement of strategic management by the position of the enterprise in the market]. Jevropejsjkyj vektor ekonomichnogho rozvytku. (2 (15)). 187-204 [in Ukrainian].

10. Fedorenko, M.M. (2010). Adaptacija modeli upravlinnja zapasamy dlja nestandartnykh sytuacij $\mathrm{z}$ urakhuvannjam pryncypu zvorotnogho zv'jazku na pidpryjemstvi «Aleks i K» [Adaptation of inventory management model for non-standard situations, taking into account the principle of feedback at Alex \& K]. Visnyk Donecjkoji akademiji avtomobiljnogho transportu. (1). 25-30 [in Ukrainian].

УДК 339.138:339.9.012

Лопушинська О.В., асистент

Панова Я. Г., здобувач вищої освіти

Стовба А. О., здобувач вищої освіти

Полтавська державна аграрна академія

\section{ОСОБЛИВОСТІ УПРАВЛІННЯ МАРКЕТИНГОВОЮ ДІЯЛЬНІСТЮ НА ПІДПРИСМСТВАХ КОНДИТЕРСЬКОЇ ГАЛУЗІ ПРИ ЗДІЙСНЕННІ ЗЕД}

В процесі управління зовнішньоекономічною діяльністю підприємства намагаються не тільки максимізувати прибуток, а й сприяти ефективній маркетинговій діяльності. Саме тому вибір маркетингової стратегії, яка б відповідала всім вимогам самого підприємства, забезпечувала ефективну та рентабельну роботу, приносила прибуток та сприяла подальшому його розвитку, є дуже важливим. В статті визначено роль процесу управління маркетинговою діяльність на підприємстві при здійсненні ЗЕД, досліджено основні елементи системи управління маркетинговою діяльністю ПАТ «Полтавакондитер» та надано рекомендацій щодо розробки маркетингових стратегій і тактик даного підприємства при здійсненні ЗЕД.

Ключові слова: управління маркетинговою діяльністю, ЗЕД, «Полтавакондитер», маркетингова стратегія, маркетинг, менеджмент

\section{Lopushynska O., Panova Ya., Stovba A.}




\section{FEATURES OF MANAGEMENT OF MARKETING ACTIVITIES AT CONFECTIONERY INDUSTRY WHEN PERFORMING FEA}

In the process of managing foreign economic activity, enterprises try not only to maximize profits, but also to promote effective marketing activities. That is why choosing a marketing strategy that meets all the requirements of the enterprise itself, ensures efficient and cost-effective operation, generates profit and contributes to its further development is very important. The article defines the role of the process of marketing activity management at the enterprise in the implementation of FEA, investigates the basic elements of the system of marketing activity management "Poltavakonditer" and provides recommendations on the development of marketing strategies and tactics of the enterprise in the implementation of FEA.

Key words: marketing activity management, FEA, Poltavakonditer, marketing strategy, marketing, management.

Лопушинская Е., Панова Я., Стовба А.

\section{ОСОБЕННОСТИ УПРАВЛЕНИЯ МАРКЕТИНГОВОЙ ДЕЯТЕЛЬНОСТЬЮ НА ПРЕДПРИЯТИЯХ КОНДИТЕРСКОЙ ОТРАСЛИ ПРИ ОСУЩЕСТВЛЕНИИ ВЭД}

В процессе управления внешнеэкономической деятельностью предприятия стараются не только максимизировать прибыль, но и способствовать эффективной маркетинговой деятельности. Именно поэтому выбор маркетинговой стратегии, которая бы отвечала всем требованиям самого предприятия, обеспечивала эффективную и рентабельную работу, приносила прибыль и способствовала дальнейшему его развитию, является очень важным. В статье определены роль процесса управления маркетинговой деятельности на предприятии при осуществлении ВЭД, исследованы основные элементы системы управления маркетинговой деятельностью «Полтавакондитер» и предоставлено рекомендации по разработке маркетинговых стратегий и тактик данного предприятия при осуществлении ВЭД.

Ключевые слова: управление маркетинговой деятельностью, ВЭД, «Полтавакондитер», маркетинговая стратегия, маркетинг, менеджмент

Постановка проблеми у загальному вигляді i ïi зв'язок 3 важливими науковими та практичними завданнями. На сьогоднішній день діяльність підприємства на зовнішніх ринках є запорукою успішної роботи. Під час здійснення зовнішньоекономічної діяльності підприємство займається не тільки реалізацією власної продукції, а й отримує доступ до великої кількості інформації та технологій. Менеджмент зовнішньоекономічної діяльності підприємства має за мету не тільки максимізацію прибутку, а й сприяти ефективній маркетинговій діяльності. Саме тому правильний вибір маркетингової стратегії, що буде відповідати всім цілям діяльності підприємства, забезпечувати ефективну роботу, приносила прибуток, збільшувала показники рентабельності та сприяла подальшому його розвитку, $є$ дуже важливим завданням для керівництва.

В сучасних умовах господарювання в Україні існують підприємства, продукція яких $є$ конкурентоздатною не тільки на вітчизняному ринку. Такі підприємства за допомогою удосконалення системи управління маркетинговою діяльністю в процесі здійснення ЗЕД 3 метою збільшення обсягу реалізації та більш ефективного використання виробничих потужностей шукають нові ринки збуту своєї продукції. В процесі розробки стратегії виходу на зовнішній ринок важливо брати до уваги наявність великої кількості обмежень і перешкод у міжнародній торгівлі, до яких належать: митні тарифи, політична і економічна нестабільність, культурні та соціальні відмінності, коливання курсу валют, ряд нетарифних бар'єрів. Всі перераховані особливості суттєво підвищують загальний комерційний ризик підприємницької діяльності суб'єкта господарювання на міжнародному ринку. Як свідчить практичний досвід великих міжнародних корпорацій, більшість проблемних питань при здійсненні ЗЕД мають управлінський характер.

Аналіз останніх досліджень, у яких започатковано вирішення проблеми. Сучасні науковці в сфері економіки та управління велику увагу приділяють не тільки 
товаропостачанню, а й менеджменту маркетингової діяльністі під час здійснення підприємством зовнішньоекономічної діяльності.

Теоретичною основою даного дослідження є публікації І. Потапюк, Д. Фединяк, I. Тюхи, М. Мозоленко, В. Пферча, А. Рудеуліса, Н. Малхорти, С. Старостіної, С. Скибінського та інших. Наукові напрацювання цих вчених у вигляді розробки наукових концепцій, положень, висновків і рекомендацій суттєво впливають на подальший розвиток сучасної теорії управління маркетинговою діяльністю. Крім того, вони дозволяють якомога глибше усвідомити важливість і складність вирішення зазначених проблем. Проте, аналіз останніх наукових джерел даної проблематики показує, що недостатньо розробленими залишаються особливості маркетингового управління діяльністю підприємств саме при здійсненні ЗЕД.

Цілі статті. Основними цілями статті $є$ визначення ролі процесу управління маркетинговою діяльність на підприємстві при здійсненні ЗЕД, дослідження основних елементів системи управління маркетинговою діяльністю ПАТ «Полтавакондитер» та надання рекомендацій щодо розробки маркетингових стратегій i тактик даного підприємства при здійсненні ЗЕД.

Виклад основного матеріалу з повним обгрунтуванням отриманих наукових результатів. В умовах нестабільності і глобалізації економіки сучасні суб'єкти господарювання приділяють все більше уваги формуванню маркетингової стратегії як головному інструменту ведення ефективної діяльності і підвищення конкурентоспроможності підприємства в постійно мінливих умовах. Формування ефективної маркетингової стратегії - один $з$ найважливіших та найскладніших етапів процесу управління [1]. Формування механізму регулювання маркетингової діяльності під час здійснення ЗЕД являє собою застосування керівного впливу держави, міських органів влади до товаровиробників експортоспроможної продукції з метою максимізації ïx пропозиції на зовнішніх ринках. Такий механізм регулювання включає послідовне подолання товаровиробниками нижчих рівнів пропозиції товарів із недостатніми якісними характеристиками задля досягнення пропозиції на високих ієрархічних рівнях за рахунок підвищення якості товару на представницьких виставках і ярмарках.

Враховуючи це, підприємства розглядають новітні маркетингові підходи до застосування регулюючих механізмів в інтенсифікації зовнішньоекономічних зв'язків із застосуванням факторів попиту i пропозиції. А протиріччя інтересів виробників i споживачів обумовлює об'єктивну необхідність проведення маркетингових досліджень [2].

Сьогодні ПАТ «Полтавакондитер» $\epsilon$ одним 3 найбільших виробників кондитерських виробів в регіоні і поставляє свою продукцію по всій Україні и за кордон. Асортимент компанії складають понад 300 найменувань кондитерських виробів, в тому числі близько 30 видів - цукерки, печиво, мармелад, зефір, пастила і лукум. Продукція ПАТ «Полтавакондитер» $\epsilon$ прекрасним результатом роботи фахівців в області кондитерської промисловості, заснованої на використанні екологічно чистої сировині. Завдяки ретельно підібраній композиції інгредієнтів вироби мають збалансований ніжний смак i приємний аромат. Компанія постійно вдосконалює технологію виробництва всіх видів продукції, оновлює асортимент, створює нові відтінки аромату і смаку, що дозволяють задовольнити потреби кожного покупця [3].

Підприємство ефективно співпрацює з інвестиційним фондом «Sigma Blayzer», завдяки чому був реалізований масштабний проект нової будівлі «Полтавакондитер». Крім того, слід відзначити співпрацю з італійською фірмою «Laser», завдяки якій було встановлено нові лінії з виробництва цукрового печива та печива 3 фруктовими наповнювачами та швейцарською «Buller», що повністю автоматизувала шоколадний цех. Продукцію полтавських кондитерів можна знайти не тільки на прилавках України, a i далеко за iii межами. Росія, Естонія, Білорусія, Грузія, Казахстан, Фінляндія, Азербайджан, Монголія, Грузія, Молдавія, Таджикистан, Киргизія, Туркменія, Естонія, Литва, Латвія, Кіпр і США гідно оцінили полтавські солодощі виробництва ПАТ «Полтавакондитер» [3]. 
Доцільно виділити основні напрями маркетингової діяльності ПАТ «Полтавакондитер» при здійсненні ЗЕД: цінова, товарна, збутова та комунікаційна політика підприємства. До особливостей продукції ПАТ «Полтавакондитер» належать: сумісність товару, простота, відносні переваги, широкий асортимент товарів, який постійно поповнюється інноваційною продукцією. Одним із важливих елементів маркетингової діяльності ПАТ «Полтавакондитер» на зовнішньому ринку $є$ цінова політика. Виробнича собівартість кондитерських виробів постійно зростає, в результаті чого збільшується ціна товару. ПАТ «Полтавакондитер» застосовує пряму маркетингову політику. Виходячи із даної стратегії підприємства, метою ціноутворення підприємства є отримання стабільного прибутку і підвищення ефективності діяльності, а також не тільки збереження обсягів товарообороту, а і його приросту. Для збуту своєї продукції ПАТ «Полтавакондитер» використовує такі засоби, як реклама, прогресивна або регресивна винагорода (за результатами обсягу продажу), боніфікація (фіксований відсоток об'єму продажу), подарунки постійним клієнтам, надання знижок і пільги визначеним категоріям клієнтів. ПАТ «Полтавакондитер» застосовує такі методи просування товару, як стимулювання збуту та особистий продаж [4].

Всі підприємства задля підвищення ефективності діяльності і збільшення конкурентоспроможності повинні особливу увагу приділяти створенню індивідуальної маркетингової стратегії, яка залежить переважно від стадії життєвого циклу, структури галузі, масштабів діяльності конкурентів тощо. Після виходу підприємства на зовнішні рики, керівництво стикається 3 жорстокою конкурентною боротьбою. Саме на основі маркетингової стратегії здійснюється більшість комерційних операцій на зовнішньому ринку.

ПАТ «Полтавакондитер» доцільно використовувати міжнародну маркетингову стратегію диверсифікації і сегментації. Сутність стратегії диверсифікації в діяльності ПАТ «Полтавакондитер» полягає в освоєнні нових зовнішніх ринків 3 метою розширення меж діяльності. Стратегія сегментації ПАТ «Полтавакондитер» полягає в поглибленні насиченості власною продукцією всіх груп споживачів, вибір максимальної глибини ринкового попиту.

У відповідності до стратегій диверсифікації та сегментації ПАТ «Полтавакондитер» пропонується використовувати три типи міжнародних маркетингових стратегій: атакуючу, оборонну, відступну. Виходячи з цілей та завдань ПАТ «Полтавакондитер», нами спрогнозовано можливий вибір тієї чи іншої стратегії міжнародної маркетингової діяльності для даного підприємства (табл. 1)

Таблиця 1

Стратегії маркетингової діяльності ПАТ «Полтавакондитер» при здійсненні ЗЕД

\begin{tabular}{|c|c|c|c|c|c|c|}
\hline $\begin{array}{c}\text { Напрямки } \\
\text { стратегії розвитку }\end{array}$ & $\begin{array}{c}\text { Типи } \\
\text { міжнародноїм } \\
\text { аркетинго-вої } \\
\text { стратегії } \\
\end{array}$ & 2014 рік & 2015 рік & 2016 рік & 2017 рік & 2018 рік \\
\hline \multirow{3}{*}{ Диверсифікація } & Атакуюча & & & & & \\
\hline & Оборонна & & & & & \\
\hline & Відступу & & & & & \\
\hline \multirow{3}{*}{ Сегментація } & Атакуюча & & & & & \\
\hline & Оборонна & & & & & \\
\hline & Відступу & & & & & \\
\hline
\end{tabular}

Атакуюча стратегія, або стратегія наступу, передбачає активну, агресивну позицію ПАТ «Полтавакондитер» на зовнішньому ринку і має за мету завоювати і розширити 
частку ринку, довести іiі до оптимальної. Оптимальним вважається сегмент, де присутні до 20 \% споживачів даного ринку, які можуть придбати до 80 \% товарів чи послуг. Якщо ця частка нижче оптимального рівня, то підприємство повинно зробити вибір: або прийняти заходи до іï розширення, або залишити той чи інший ринок. Оборонна стратегія передбачає збереження для ПАТ «Полтавакондитер» тієї ринкової частки, якою воно володіє. Така стратегія обирається у випадку, якщо ринкова позиція підприємства задовільна, або у неї для проведення активної агресивної політики не вистачає коштів і ресурсів. Такий тип стратегії досить небезпечний і потребує великої уваги до дій своїх конкурентів. Стратегія відступу - це вимушена, а не обрана стратегія. Вона передбачає поступове скорочення торгівельних операцій і ліквідацію бізнесу. У цьому випадку важливо не допустити втрати інформації про ліквідацію комерційної діяльності.

Тактика міжнародного маркетингу в системі управління ПАТ «Полтавакондитер» повинна розроблятися на найближчі рік-півтора і регулярно, не очікуючи закінчення цього терміну, має перевірятися і корегуватися. Найбільш доцільною вважаємо таку тактику міжнародних маркетингових дій ПАТ «Полтавакондитер» на зовнішньому ринку (табл. 2).

Таблиця 2

Тактика міжнародних маркетингових дій ПАТ «Полтавакондитер» на зовнішньому ринку на 2020 рік

\begin{tabular}{|c|c|c|c|c|c|c|c|c|c|c|c|c|}
\hline \multirow[b]{2}{*}{ Міжнародні маркетингові заходи } & \multicolumn{12}{|c|}{ Місяці року } \\
\hline & $\sigma$ & ฮิ & 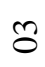 & t & 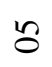 & 8 & s & $\stackrel{\infty}{\circ}$ & 8 & 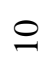 & $=$ & $\simeq$ \\
\hline Розробка заходів з активізації діяльності & & & & & & & & & & & & \\
\hline Прямі контакти із споживачами & & & & & & & & & & & & \\
\hline Розробка графіку рекламної кампанії & & & & & & & & & & & & \\
\hline Вихід на нові регіональні ринки & & & & & & & 皿 & & & & & \\
\hline Постійна презентація товарів чи послуг & 带 & & & & & & & & & & & \\
\hline $\begin{array}{l}\text { Міжнародні маркетингові дослідження нових } \\
\text { зарубіжних ринків }\end{array}$ & & & & & & & & & & & & \\
\hline $\begin{array}{l}\text { Адаптація товарів та послуг до вимог } \\
\text { споживачів }\end{array}$ & & & & & & & & & & & & \\
\hline Підвищення ефективності сервісу & & & 艮 & & & 䐬 & & & 䐬 & & & \\
\hline $\begin{array}{l}\text { Контроль та корегування тактики } \\
\text { міжнародного маркетингу }\end{array}$ & & & & & & & & & & & & \\
\hline
\end{tabular}

Крім того, до найбільш поширених тактичних міжнародних маркетингових заходів, які доцільно використовувати ПАТ «Полтавакондитер», потрібно віднести наступні: ефективні дії по просуненню товарів на зовнішній ринок; адаптація товару та послуг до вимог іноземного споживача; підвищення ефективності сервісу; прямі контакти зі споживачами; рекламні заходи за системою «директмейл»; міжнародні маркетингові дослідження ринків; розширення асортименту продукції; швидке реагування на листи та запити клієнтів.

Висновки. Управління маркетинговою діяльністю підприємств при здійсненні ЗЕД необхідно розглядати як комплексну систему заходів з організації менеджменту виробничо-збутової діяльності, що базується на вивченні ринку кондитерських виробів 3 метою максимального задоволення в ній потреб покупців, де кінцевою метою $\epsilon$ одержання прибутку за рахунок розширення обсягів продажу виробленої продукції і послуг у результаті проведення цілеспрямованої збутової політики. Окрім українських ринків, продукція торгової марки «Домінік» є досить популярною на ринках Росії, Казахстані, Фінляндії, Азербайджані, Монголії, Грузії, Молдавії, Таджикистані, Киргизії, Туркменії, Естонії, Литві, Латвії. Основними видами маркетингової стратегії 
при здійсненні ЗЕД, які доцільно використовувати ПАТ «Полтавакондитер», є стратегії диверсифікації і сегментації. Крім того, в процесі дослідження управління маркетинговою діяльністю підприємства при здійсненні ЗЕД актуальними є питання комунікативної політики на міжнародному ринку, що i буде предметом наших подальших досліджень.

\section{Список бібліографічного опису:}

1. Фединяк Д. П. Маркетингові стратегії проникнення підприємства на зовнішні ринки [Електронний ресурс]. - Режим доступу: http://dspace.tneu.edu.ua/bitstream/316497/963/1/Fedynyak\%20D.P.\%2C\%20MUNzmi-51.pdf

2. Тюха I. В. Особливості управління маркетингом на підприємстві при здійсненні зовнішньоекономічної діяльності / I. В. Тюха, М. С. Мозоленко // Ефективна економіка. - №1, 2016. Режим доступу: http://www.economy.nayka.com.ua/?op=1\&z=4725

3.Офіційний сайт компанії ПАТ «Полтавакондитер» [Електронний ресурс].- Режим доступу: https://dominik.ua

4. Потапюк I. П. Товаропостачання як елемент управління маркетинговою діяльністю підприємства на ринку кондитерських виробів / І. П. Потапюк, О. Ю. Бовт // Економічний форум №4. - Луцьк: Редакційно-видавничий відділ Луцького НТУ, 2015. - С. 320-325.

\section{References:}

1. Fedinyak D.P. Marketing strategies of enterprise penetration into foreign markets [Electronic resource]. - Access mode: http://dspace.tneu.edu.ua/bitstream/316497/963/1/Fedynyak\%20D.P.\%2C\%20MUNzmi-51.pdf

2. Tyukha I. V. Peculiarities of marketing management in an enterprise in the implementation of foreign economic activity / I.V. Tyukha, M.S. Mozolenko // Effective Economics. - №1, 2016. Access mode: http://www.economy.nayka.com.ua/?op=1\&z=4725

3.Official site of Poltavakonditer [Electronic resource] .- Access mode: https://dominik.ua

4. Potapyuk I.P. Commodity Supply as an Element of Managing the Marketing Activity of an Enterprise in the Confectionery Market / I.P. Potapyuk, O. Yu. Bovt // Economic Forum №4. - Lutsk: Editorial and Publishing Department of Lutsk NTU, 2015. - P. 320-325.

Реиензент д.е.н., професор Маркіна I.А.

УДК 316.6:331.1:338.2

Сазонова Т. О., к.е.н., доцент,

Єріна В. В., здобувач вищої освіти

Полтавська державна аграрна академія

\section{РОЛЬ ПСИХОЛОГІЧНИХ МЕТОДІВ УПРАВЛІННЯ У ФОРМУВАННІ ЕФЕКТИВНОЇ ДІЯЛЬНОСТІ ПІДПРИЕМСТВА}

Досліджені психологічні аспекти трудової діяльності. Запропонована архітектура системи психологічного управління персоналом організації. Обгрунтована пріоритетність психологічних методів в управлінні, визначена їх ролі у формуванні ефективної діяльності сучасного підприємства. Охарактеризована система психологічних методів управління. Сформовані правила ефективного застосування психологічних методів управління. Наведені індикатори успішності застосування керівництвом психологічних методів управління персоналом організації.

Ключові слова: психологічні методи управління, персонал, ефективність організації, мотивація, залучення, результативність.

\section{THE ROLE OF PSYCHOLOGICAL MANAGEMENT METHODS IN THE FORMATION OF EFFECTIVE ENTERPRISE}

Psychological aspects of work activity were investigated. The architecture of the system of psychological personnel management organization was offered. The priority of psychological management methods was substantiated; their role in forming effective activity of modern enterprise was defined. The system of psychological management methods was characterized. The rules of effective application of psychological methods of management have been formed. Indicators of success of the application of psychological personnel management methods of the organization by the management were given.

Keywords: psychological management methods, personnel, organization effectiveness, motivation, involvement, performance. 